\title{
Influence of Selected Factors on Students' Attitude towards Physics in Public Secondary Schools
}

\author{
Nicholas Muriuki Nteere ${ }^{1, *}$, Jacob Mwenda Kwaria ${ }^{2}$, Newton Kiogora Kirimi ${ }^{3}$ \\ ${ }^{1}$ Department of Education and Social Sciences, Kenya Methodist University, Meru, Kenya \\ ${ }^{2}$ Department of Education, Africa Nazarene University, Nairobi, Kenya \\ ${ }^{3}$ Department of Mathematics and Statistics, Jomo Kenyatta University of Agriculture and Technology, Kenya \\ *Corresponding author: professornicholasthegreat@gmail.com
}

\begin{abstract}
The study investigated students' attitude towards selection of Physics in secondary schools. Questionnaires with items set to capture data on the study objectives were administered to three hundred and sixty one students selected proportionally and randomly from forty two public secondary schools. Physics teacher in each school was involved. The data collected was analyzed using descriptive parameters and few inferential statistics. Physics teacher as a role model and perceived subject abstractness by the students had significant influence on students' attitude towards selection of Physics in Meru Central Sub County. It was concluded that, Physics teacher as a role model and perceived subject abstractness by the students played an important role on students' attitude towards selection of Physics.
\end{abstract}

Keywords: student, selection, perceived abstractness, role model, physics

Cite This Article: Nicholas Muriuki Nteere, Jacob Mwenda Kwaria, and Newton Kiogora Kirimi, "Influence of Selected Factors on Students' Attitude towards Physics in Public Secondary Schools." American Journal of Educational Research, vol. 5, no. 9 (2017): 939-943. doi: 10.12691/education-5-9-2.

\section{Introduction}

Physics is the study of energy and matter and exactly how they affect each other. Physics is the basis of technology and for effective living in the contemporary age of science and technology, it is essential that every child should be given the opportunity to acquire at least basic knowledge and the concept of physics as a science. However, Physics teacher as a role model and perceived subject abstractness by the students influence students' attitude towards selection of Physics in secondary school. Many developing countries are striving to enhance industrialization in return improving their economy. To improve industrialization in Kenya one avenue is to have sciences as key subjects in secondary schools as echoed in the Kenya Vision 2030 implementation plan and policies for industrialization [1]. Physics and Biology are the key alternative laboratory science subjects to the majority of the students in secondary school in Kenya [2]. In the Kenya gazette, KNEC is the only mandated examining body for basic education. At secondary level a candidate must fulfill several requirements in order to be eligible for grading. Among them is that as a candidate the student must have been preparing to sit for at least two laboratory science subjects which include Biology, Physics and Chemistry. The Ministry of Education curriculum implementation policy states that a student who joins high school should be exposed to all laboratory science subjects for a period of two years KNEC [3], from when they are then expected to choose the subjects to concentrate on. A pre-research done by the researcher showed that Chemistry subject is taught at all classes across the sub county. This means that students are left to either take the rest two subjects in the group or choose one and drop the other in order to fulfill the KNEC requirement. The researcher associated the selection of the subject to continue with to several factors and therefore the researcher sought to investigate the influence Physics teacher as a role model and perceived subject abstractness by the students. Moore [4] defined an attitude as a mental or neural state of readiness, organized through experience, exerting a directive or dynamic influence on the individual's response to all objects and situations to which it is related. In line with the study, the students' attitudes towards selection of Physics can be related to the state of readiness and individual response to situations. Attitudes are a complex combination of things we tend to call personality, beliefs, values, behaviors, and motivations. Students' attitudes towards selection of Physics can be attributed to values of the subject as well as motivation towards choosing from different forces. According to Freud [5] attitude formation is a result of learning, modeling others, and our direct experiences with people and situations. Attitudes influence our decisions, guide our behavior, and impact what we selectively remember (not always the same as what we hear). The researcher considered that the students' attitudes towards selection of Physics could be influenced by learning situations, role models which leads to selective decision. To change a person's attitude you need to address the cognitive and emotional components. Attitude transformation takes time, effort, and determination, but it can be done. It is 
important not to expect to change a person's attitudes quickly [6]. The researcher was in agreement that statement that the students' attitudes towards selection of Physics required time, effort and determination. The researcher believed that with adequate time, determination by the school systems, effort exerted by the Physics teacher and collective motivation by the relevant bodies could lead to the change of attitude of the students' selection of Physics in secondary schools in Meru Central Sub County. From the previous studies across the world, it was clear that the number of learners choosing Physics at the appropriate selection period is low. Several ways of combating low selection of Physics subject at the appropriate selection period by students have been recommended by the studies. In Meru Central Sub County, ways to combat low number of learners choosing Physics have not yet stabilized since the number of students in the region sitting for Physics subject in the K.C.S.E. is lower than the number of students who have enrolled for the alternative science subject which is Biology in each year. This is evidenced by the K.C.S.E. percentage candidature for Physics subject in the years 2009 to 2013 in Meru Central Sub County were $19.98 \%, 21.05 \%, 20.72 \%$, $20.88 \%$ and $18.69 \%$ as compared to $80.02 \%, 78.95 \%$, $79.30 \%, 79.20 \%$ and $81.31 \%$ for Biology. This study sought to find out whether Physics teacher as a role model and perceived abstractness of Physics by the students were contributing factors to low selection of Physics in secondary schools in Meru Central Sub County.

\section{Research Hypotheses}

In the study the following hypotheses were tested;

i. Physics teacher as a role model has no statistically significant influence on students' attitude towards selection of Physics in secondary school students' in Meru Central Sub County.

ii. Perceived subject abstractness by the students has no statistically significant influence on students' attitude towards selection of Physics in secondary school in Meru Central Sub County.

\section{Theoretical Framework}

According to Osborne, Simon and Collins [7], Ajzen and Fishbein's (1980), theory of reasoned action, is concerned fundamentally with predicting behaviour. The theory focuses on the distinction between attitudes towards some 'object' and attitudes towards some specific action to be performed towards that 'object' (for example, between attitudes towards science and attitudes towards doing school science). Ajzen \& Fishbein (1980) argue that it is the latter kind of attitude that best predicts behaviour. Theory of reasoned action represents a relationship between attitude, intention and behaviour. Behaviour is seen as being determined by intention and in turn, is a joint product of attitude towards the behaviour and the subjective norm, like beliefs about how other people would regard one's performance of the behaviour (Ajzen \& Fishbein, 1980). Crawley and Black [8], Simpson and Oliver [9] applied the theory of reasoned action in some attitude and behaviour studies in science education and found it to be successful. They also noted that social support from peers and attitude towards enrolling for a course are strong determinants of student choice to pursue science courses voluntarily, which suggests that the theory has at least some partial validity. The main value of such a theory is that it helps in determining salient beliefs that can then be reinforced or downplayed to affect relevant behavioural decisions by students. The theory of reasoned action emphasizes that there is need to draw a demarcation between school science and science in society. It is the perception of school science, and the feelings towards the 'behaviour' of undertaking a further course of study in that context, which are most significant in determining students' decisions about whether to proceed with further study of science. In context to this study the researcher opted to apply the theory of reasoned action in the study to investigate the influence of Physics teacher as a role model and perceived abstractness on students' attitudes towards selection of Physics in secondary school in Meru Central Sub County.

\section{Literature Review}

A study by Alberta Education [10] in Canada demonstrated that students' perceptions about subjects are influenced by their parents, peers, the media, and their teachers. Teachers and peers that are involved with high school Physics should be communicating their perceptions to students unsure of their academic futures. A study in Israel conducted by Mualem and Eylon [11] discussed the effects of teachers' perceptions on their students, an important area to address when contemplating where students get their presumptions of Physics. The results showed that although the western educational community believes in the importance of exposing students to Physics at the junior high school level, many junior high school students have difficulty in understanding Physics conceptually and have a distress of Physics at the junior high school level. Research has demonstrated that the attitudes toward Physics change with exposure to Physics and its related activities. But the direction of change may be related to the quality of that exposure, the learning environment, and teaching method $[12,13]$. However, the attitude does not stay the same, it changes in the course of time and the experiences. Knowledge and skills change the beliefs and attitudes of the individuals regarding the difficulty of Physics by gaining problem solving skills. Problem-solving also involves a student's willingness to accept challenges.

Eccles, [14]; Erdemir, and Bakırc1, [15]. Yildiz, Akpinar, Aydogdu and Ergin [16] urges that the Physics teacher as the guide, consultant, mentor and moderator should play a big role in imparting skills and knowledge by implementing teaching methods and classroom activities that will change the attitude of the students toward the Physics. The study investigated the influence of a teacher as role model/mentor on the selection of Physics in secondary school in Meru Central Sub County. From the literature review studies by Alberta Education [10] in Canadian, Mualem \& Eylon [11] Yildiz, Akpinar, Aydogdu and Ergin [16], it was observed that the Physics 
teacher should act as a guide, consultant, mentor and moderator to students. The teacher play a big role in imparting skills and knowledge by implementing teaching methods and classroom activities that will change the attitude of the students toward the Physics. The study sought to fill the gap by investigating whether Physics teacher act as a role model influence students' attitude towards selection of Physics since no other study similar to this has been carried out in the Meru Central Sub County.

According to Henriksen, Lavonen, Angell, Bymen and Koponen [17], little research has been done on students' perceptions about Physics and Physics learning, but few studies carried out previously, on average, researchers have noted that Physics is described as "hard". Individuals have a different opinion about what, in particular, is difficult about Physics. Some find the algebraic emphasis difficult, and some find the physical concepts difficult to wrap their mind around. Others comment that the workload, or the level of critical thought required, is intimidating thus causing general fear of Physics in our society [18]. Henriksen et al [17], in a study carried out in Finland, noted that much of the Physics curriculum is often considered boring by students. A study in Canada noted that far fewer students were taking Physics than the other sciences at the high school level. They related this to lack of the necessary mathematics skill; however, it was not the major issue since just as many students complete the highest level mathematics classes as Chemistry and Biology. Angell et all, [18], in their study to examine the impact of mathematics on Physics enrolment noted that the Physics teachers perceived, the Physics subject to be more of a problem than the students did perceive. It also demonstrated that the students claimed that the mathematics in Physics was not that difficult but claimed that what made the course difficult was the fast progression of topics and the large amount of curriculum content, two realms that obviously influence each other. Since no study on how student's perceived abstractness on Physics has been carried out in Meru Central Sub County the study was focused on closing that gap the gaps created by previous studies that the involvement of mathematical and analytical problem in the subject, as noted by Angell et all, [18], failure of students to understand how useful Physics was in their day to day lives and considering it to be boring as observed by [17].

Vision 2030 was established in 2012 to be a blue print in guiding Kenya's social and economic development to its realization of being a middle income industrialized country. Key to this development is adequate scientists especially in Physics. Despite this, scientists competent in Physics are very few due to the very low choice of the Physics subject in secondary schools and inevitably technical colleges and universities. The literature reviewed in the study demonstrated that perception and enrolment, attitude of parents towards science, anxiety towards Physics, fear of failure on course, societal factors, relevance of Physics, nature of the classroom and gender issues, positively influenced selection of Physics by students at secondary school level. Policies for industrialization and having science as the key subject in education at secondary schools should be achieved in order for Kenya to realize Vision 2030 goals on increasing the levels of industrialization. The study was carried out in Meru Central Sub County in Kenya to explain whether significantly Physics teacher as a role model and the perceived abstractness of Physics by the student significantly influenced selection of Physics in secondary schools.

\section{Methodology}

The study adopted descriptive research design, and more specifically correlational research design. This design was suitable since it aided in explaining the level of influence of Physics teacher as a role model and perceived abstractness of the subject on selection of Physics in secondary schools. Correlational research design helped combine both qualitative and quantitative data to generate test statistics used in hypothesis testing to make decisions on whether the individual variables significantly influenced the selection of Physics in secondary schools. Proportionate technique was used to determine the number of students from each school and class. Random sampling was done and a sample size of 361 students was determined. Purposively a Physic teacher from each of 42 secondary schools was selected thus 42 Physics teachers was involved in the study.

\section{Research Instruments}

For the purpose of data collection, in order to provide answers to the formulated research objectives, and to ensure adequate coverage, the instrumentation that were used are questionnaires and an interview schedule.

The questionnaires were of two (2) types:

1. Form one and two student's questionnaire

2. Form three and four student's questionnaire.

Each questionnaire was divided into two parts, section A which captured the demographic information of the students. This was to ensure that the researcher could be able to understand the age factor, gender and the present class. The form 3 and 4 questionnaire captured, the science subjects done by the students. The section B of the questionnaires, comprised of the items that were set according to the study objectives. The questionnaires provide Likert scale responses. [19]. The number of respondents giving each type of response will be counted and scored. The Physics teacher's interview schedule was comprised of probe questions. All geared to capture relevant information on the study objectives. The interview schedule yielded qualitative data.

\section{Instrument validity and Reliability}

Further validation of the instrument was to ensure that all the items in each instrument were based on the set study objectives. Two sets of data from each instrument were used to compute the content validity index for the instrument. The content validity indexes for form 1 and 2 questionnaire, form 3 and 4 questionnaire and the Physics teacher's interview schedule were $0.73,0.68$ and 0.69 , respectively. Since all the content validity indexes were 
greater than both values were greater than 0.6 all the instruments were considered valid Jeffry, [20] for the study. The reliability of the instrument was ensured by checking whether the respondent's answers were consistent with the expected responses. Two data sets for each instrument were used to compute the Spearman Brown Correlation Coefficients. The coefficients for the Form One and Form Two groups, Form Three and Form Four group and the Physics teacher's interview schedule were $0.63,0.66$ and 0.682 respectively. Korb [21] advice that if the computer reliability index was greater than 0.60 then the tool or test is reliable hence the tools were considered reliable for the study.

\section{Data Analysis}

The quantitative data was analyzed using the Statistical Package for Social Sciences (SPSS) version 22.0. Descriptive statistics involved the use of means, standard deviations and percentages while an inferential statistical test was used to test the hypothesis. The hypotheses were tested at $5 \%$ level of significance to determining whether to accept or reject. Regression coefficients were used to explain the magnitude of influence of the variables investigated in the study.

\section{Findings and discussions}

The data analysis and results are presented with special reference to the research hypothesis tested in the study. The descriptive statistics means and standard deviations were interpreted using a scale that ranged between 1 and 2 . A value of the mean between 1 and 1.3 meant the group was in agreement, 1.4 to 1.6 meant the group was not uncertainty while 1.7 to 2 meaning disagreement.

Table 1. Descriptive Statistics

\begin{tabular}{lcc}
\hline & $\begin{array}{c}\text { Overall } \\
\text { Mean }\end{array}$ & $\begin{array}{c}\text { Standard } \\
\text { deviation }\end{array}$ \\
\hline $\begin{array}{l}\text { Physics teacher as a role model on students' } \\
\text { attitude towards selection of Physics }\end{array}$ & 1.2567 & 1.1972 \\
$\begin{array}{l}\text { Perceived subject abstractness by the students } \\
\text { on students' attitude towards selection of }\end{array}$ & 1.3213 & 1.1553 \\
$\begin{array}{l}\text { Physics } \\
\begin{array}{l}\text { Students' attitude towards selection of } \\
\text { Physics }\end{array}\end{array}$ & 1.0023 & 0.87453 \\
\hline
\end{tabular}

Influence of Physics teacher as a role model on students' attitude towards selection of Physics in secondary school students' in Meru Central Sub County.

A mean of 1.2567 in Table 1 implies that generally a majority of the students were in agreement that there physics teacher a role model influenced the students' attitude towards selection of physics. The hypothesis which stated that Physics teacher as a role model has no statistically significant influence on students' attitude towards selection of Physics in secondary school students' in Meru Central Sub County was tested. Results shown in Table 3 indicated that $(p=0.0213)$ at $5 \%$ level of significance showed that there was statistically significant influence between physics teacher as a role model and students' attitude towards selection of physics in secondary school in Meru Central Sub County. The null hypotheses was thus rejected. This finding was in agreement with [15] that the Physics teacher should act as the guide, consultant, mentor and moderator in order to play a big role in changing students' attitude towards selection of Physics.

Influence of Perceived subject abstractness by the students on students' attitude towards selection of Physics in secondary school students' in Meru Central Sub County.

A mean of 1.3213 in Table 1 implies that generally a majority of the students were in agreement that perceived physics abstractness by the students influenced the students' attitude towards selection of physics. When the hypotheses which stated that "Perceived subject abstractness by the students has no statistically significant influence on students' attitude towards selection of Physics in secondary school students' in Meru Central Sub County". Results shown in Table $3(p=0.01464)$ at $5 \%$ level of significance led to rejection of the null hypotheses. This showed that there was statistically significant influence between Perceived subject abstractness by the students and students' attitude towards selection of physics in secondary school in Meru Central Sub County. This finding was consistent with Lavonen Gedrovics, Byman, Meisalo, Jutti, \& Uitto [13] in a study carried in Ireland who noted that much of the Physics curriculum is often considered boring by students.

To find out what proportion of students' attitude towards selection of physics can be explained by the two variables investigated a multiple regression analysis was carried out.

Table 2. Model summary

\begin{tabular}{ccccc}
\hline Model & $\mathbf{R}$ & $\mathbf{R}^{2}$ & $\begin{array}{c}\text { Adjusted } \\
\mathbf{R}^{2}\end{array}$ & $\begin{array}{c}\text { Standard error of the } \\
\text { estimate }\end{array}$ \\
\hline 1 & $0.8993^{\mathrm{a}}$ & 0.8087 & 0.7564 & 5.9743
\end{tabular}

a. Predictors: Physics teacher as a role model, Perceived subject abstractness by the students

From the Table 2 the multiple correlation coefficient $(\mathrm{R}=0.8993)$ is the correlation between the students' attitude towards selection of physics reported by the respondents and the students' attitude towards selection of physics predicted by the two independent variables investigated in the study. A value of (R-0.8993) indicated a good prediction. The coefficient of determination $\left(\mathrm{R}^{2}=0.8087\right)$ indicated the proportion of the variance in the dependent variables (students' attitude towards selection of physic) which is accounted for by the model. This implies that $80.87 \%$ of the variability in students' attitude towards selection of physic can be explained by the two variables Physics teacher as a role model, Perceived subject abstractness by the students. The rest $(19.12 \%)$ could be explained by other variables not included in the study. To find out which of the independent variables was most significant in influencing the students' attitude towards selection of physic a multiple regression analysis was performed. The SPSS output is shown in Table 3. 
Table 3. Summary of Coefficients

\begin{tabular}{lccccc}
\hline \multicolumn{7}{c}{$\begin{array}{c}\text { Unstandardized } \\
\text { Coefficients }\end{array}$} & $\begin{array}{c}\text { Standardized } \\
\text { Coefficients }\end{array}$ & & \\
\hline \multicolumn{1}{c}{ Model } & B & Std. Error & Beta & $\mathbf{t}_{\text {cal }}$ & Sig. \\
\hline $\begin{array}{l}\text { (Constant) } \\
\begin{array}{l}\text { Physic teacher } \\
\text { as role model }\end{array}\end{array}$ & 1.233 & 0.0462 & & 6.432 & 0.000 \\
$\begin{array}{l}\text { Perceived } \\
\text { Abstractness }\end{array}$ & 2.017 & 0.0608 & 2.6589 & 17.333 & 0.000 \\
\hline
\end{tabular}

From the results in Table 3 the unstandardized regression coefficients (B) indicated how much the dependent variable (students' attitude towards selection of physics varies with an independent variable, when all the other variables are held constant. Thus the higher the B-Value the greater the influence the independent variable has on the dependent variable. Perceived subject abstractness by the students with an unstandardized 2.017 and a standardized coefficient (Beta) 2.6589 were reported to be the most significant in influencing students' attitudes towards selection of physics. This means that a one-unit increase in perceived subject abstractness by the students would yield a 2.017 unit increase in the predicted students' attitude towards selection of physics. Similarly, for the standardized coefficient (Beta), a one standard deviation increase in Perceived subject abstractness by the students would yield a 2.6589 standard deviation increase in the predicted students' attitude towards selection of physics. Physics teacher as a role model had an unstandardized 1.684 and a standardized coefficient (Beta) 2.1114. This means that a one-unit increase in Physics teacher as a role model would yield a 1.684 unit increase in the predicted students' attitude towards selection of physics. Similarly, for the standardized coefficient (Beta), a one standard deviation increase in Physics teacher as a role model would yield a 2.1114 standard deviation increase in the predicted students' attitude towards selection of physics.

\section{Conclusions and Recommendations}

This study sought to find out whether Physics teacher as a role model and perceived abstractness of Physics by the students were contributing factors to low selection of Physics in secondary schools in Meru Central Sub County. The results reported strong influence on students' attitude towards selection of Physics by the variables, Physics teacher as the role model and the perceived subject abstractness by the students. It was clear that the some of the Physics teachers could not show the significance of Physics in relation to day to day life situation. Physics teachers were not fully able to make students grasp the concepts of application of Physics. Results also clearly indicated that, majority of the students claimed that Physics involved calculations hence perceived Physics difficult. This was supported by the fact, Physics teachers asserted that majority of the students had problems in mathematics and analytical aspects of Physics. The study recommended that Ministry of Education, Science and Technology in conjunction with the school management should make deliberate efforts to make workshops, in-service training and refresher courses that are students oriented to the Physics teachers. Through these programmes the Physics teachers will obtain the necessary competencies needed to make students develop positive attitudes towards Physics. Again, the Physics teachers can develop creativity and motivating skills that can make the delivery of Physics concepts easy and interesting to students.

\section{References}

[1] GOK (2013).Vision 2030 Popular Version the National Economic and Social Council of Kenya (NESC), Government Printers, Nairobi, Kenya.

[2] KNEC (2014). 2013 KCSE Examination Report. Nairobi: KNEC

[3] KNEC (2016). Act no. 29 of 2012 Report. Revised Edition 2016 [2014] Published by the National Council for Law Reporting with the Authority of the Attorney-General www.kenyalaw.org.

[4] Moore. M. (2007). Personality: A Psychological Interpretation. New York, NY: Holt Rinehart \& Winston.

[5] Freud, S. (2006). The neuro-psychoses of selection. In: The standard edition of the complete psychological works of Sigmund Freud, 3, 45-61. Translated by James Strachey. London: Hogarth Press, 2003

[6] Eagly, A., \& Chaiken, S. (2006). Revised Version of A theory of cognitive dissonance. Stanford, CA: Stanford University Press. 2005.

[7] Ajzen,I. \& Fishbein, M. (1980). Understanding attitudes and predicting social behaviour (Englewood Cliffs, NJ: Prentice Hall).

[8] Osborne J., Simon S. \& Collins S. (2003). Attitudes towards science: a review of the literature and its implications. International Journal of Science Education, 25(9), 1049-1079. Research in Science \& Technological Education, 26(2), 113-128.

[9] Crawley F. E. \& Black C. B. (1992). Causal modelling of secondary science students intentions to enroll in Physics. Journal of Research in Science Teaching, 29, 585-599.

[10] Simpson, R. D., Koballa, T. R., Oliver, S. J., \& Crawly. F. E. (1990). Research on the affective dimension in science learning. In D. Gabel (Ed.), Handbook of research on science teaching (pp. 211-236), New York: Macmillan Publishing Company, 1994.

[11] Alberta Education. (2007). Diploma Examinations Program: View Results by Table. 2008 from Alberta.

[12] Mualem R., \& Eylon B. (2009). Teaching Physics in junior high school: Crossing the borders of fear. European Journal of Teacher Education, 32(2), 135-150.

[13] Ciomos F. (2006). Students' Perception on Learning Science. Anuarul Institututîlui de pregătire didactică.

[14] Lavonen, Gedrovics, Byman, Meisalo, Jutti, \& Uitto (2008). Attitudes toward science by students enrolled in introductory level science courses. A Case of Iran. A Journal of Undergraduate Research, 9, 1-6.

[15] Eccles L. (2007). Gender differences in teacher-student interactions, attitudes and achievement in middle school science (Doctoral Thesis). Western Australia: Science and Mathematics Education Centre, Curtin University of Technology.

[16] Erdemir L.,K. \& Bakırc1 S.,W. (2009). Attitude and achievement of Bruneian science students. International Journal of Science Education, 25(8), 907-922.

[17] Yildiz E., Akpinar E., Aydogdu B. \& Ergin O. (2010). Science Teachers Attitudes towards Aims of the Science Experiments. Journal of Israel Science Education. Vol 3, (3) 125-133.

[18] Henriksen E., Lavonen J., Angell C., Bymen R., \& Koponen I. (2007). Social interaction in upper secondary Physics classrooms in Finland. A Journal in Education Research, 15(5), 207-227.

[19] Angell C., Guttersrud O., Henriksen E., \& Isnes A. (2004). Physics: Frightful, but fun. Pupils' and teachers' views of Physics and Physics teaching. A journal in Science Education, 88(5), 683-706.

[20] Bertram D. (2016) "Likert Scales." Retrieved July 18, 2016 from: http://my.ilstu.edu/ eostewa/497/Likert\%20topic-dane-likert.pdf.

[21] Jeffry M.M. (2011). Content Validity and Estimation. A Journal of Research Education. University of Colorado, Aurora, Colorado, USA 5(2) 114-127.

[22] Korb J.K (2016). A guide to appropriate choose to test reliability index of research Tool using three approach. A Journal of Sociology and Research. Vol 43(7): 669-733. University of Jonesburg South Africa. 